\title{
Design of Household Organic Waste Composter Bins "Tongposcah"
}

\author{
Rizqi Puteri Mahyudin ${ }^{1}$, Gamaliel Purba ${ }^{1}$, Yuni Safaria Dwi Lestari ${ }^{1}$, \\ Muhammad Firmansyah ${ }^{1}$
}

${ }^{1}$ Department of Environmental Engineering, Faculty of Engineering Lambung Mangkurat University Banjarbaru South Kalimantan Indonesia

Corresponding Author: Rizqi Puteri Mahyudin

DOI: https://doi.org/10.52403/ijrr.20220173

\begin{abstract}
Background and Aim: Composting method is one way of managing organic waste that can be done from the source, namely the household. Using a composter bins is designed to make it easier to handle household waste. The size of the compost raw material will affect the compost maturation time. The smaller the size of the waste, the faster the harvest period. Most of the studies that have been carried out, the design of a composter with a manual chopper can be a solution to facilitate household scale composting. This study aims to design and test the performance of a compost container equipped with a manual chopper namely "Tongposcah".

Method: The design of the composter tool is done by sketching the image using the Autocad application. The design is then carried out by assembling the tool. The assembled composer was then tested. The trial was carried out with parameter monitoring. The parameters observed included the size of the chopped particles, the capacity of organic waste and the length of time for chopping. The trial was conducted to determine the ability of the composter designed to carry out the composting process. After the trial is complete, the next tool evaluation analysis is carried out.
\end{abstract}

Results: The size of the composter bin has a height of $100 \mathrm{~cm}$, a diameter of $45 \mathrm{~cm}$ with a volume of $150 \mathrm{~L}$ which is equipped with a manual chopper mounted on the top of the container. The results of experiments in the composter performance is the composter able to produce $22,735 \mathrm{~kg}$ in one process with a processing time of 75 minutes until the bin is full. The time is influenced by the ability of human power because the tool is rotated manually. The composter is able to accommodate a total of $75 \mathrm{~L}$ of compost material, $30 \mathrm{~L}$ of leachate, this is due to the bulkhead in the equipment and leachate filtration.

Conclusion: Overview mechanically Tongposcah is able to accommodate a maximum of $15-60 \mathrm{~kg}$ of household waste, the stirrer system can rotate stably, the mixing of organic waste compost material has been stable (homogeneous), the air ventilation system as a temperature regulation can work well, the entrance and exit of compost material at the composter works well, the composter legs are sturdy and strong against rotational vibrations, the composter chopper drive lever through the rotating wheel can rotate well, the composter can hold liquid compost from leakage.

Keywords: Composter, Household Waste, Manual Chopper.

\section{INTRODUCTION}

One of the environmental problems in Indonesia is the organic waste problem. Based on Indonesia Law Number (No.) 18 of $2008^{\text {[1] }}$, waste is the residue of daily human activities and/or natural processes in solid form. Until now, the waste management paradigm used by the community is still using the collection, transport, and disposal methods. In Banjarbaru city South Kalimantan Indonesia, the generation of domestic waste per day is $0.36 \mathrm{~kg} /$ person/day or 2.64 
liters/person/day. The composition of the waste is $96.74 \%$ organic waste and $3.26 \%$ non-organic waste [2]. Household waste is the largest contributor of organic waste that goes to landfill ${ }^{[2]}$. In waste management in the city of Banjarbaru, composting is an alternative or method that can be used to utilize organic waste into compost. The obstacles in doing composting include still using the manual method [3]. Composting method is one way of managing organic waste that can be done from the source, namely the household. Using a composter bins is designed to make it easier to handle household waste. The size of the compost raw material will affect the compost maturation time. The smaller the size of the waste, the faster the harvest period. Most of the studies that have been carried out, the design of a composter with a manual chopper can be a solution to facilitate household scale composting. The volume of 1 mold of a $5000 \mathrm{~L}$ compost pile is equivalent to $+/-600 \mathrm{~kg}{ }^{[4]}$. One container can accommodate $+/-180 \mathrm{~L}$ of compost with a weight of $+/-22 \mathrm{~kg}$, can be used to process compost for 2.5-3 L/person/day of waste. The types of waste that can enter the composter are vegetable scraps, leftovers, fruit residue and leaves from the garden ${ }^{[5]}$. In aerobic composting, the composter design must pay attention to an optimal aeration system by considering the need for oxygen supply for microorganisms in the decomposition process ${ }^{[6]}$.

The purpose of this research is to design composter bin namely Tongposcah. The composter used is a manual composter. This composter is a simple technology that is appropriate for the community to process household waste. The communal composter will process organic waste from households which will be used as compost [7]. This composter is designed in such a way that it is easy to operate for a regional scale. Furthermore, the performance of the composter will be tested to produce compost with good quality, large quantity and fast composting time.

\section{MATERIALS AND METHODS Material}

The tools needed in this design are AutoCAD software, drill, grinder, tape measure, sandpaper, ruler and marker. The materials used in this design are High Density Polyethylene (HDPE) drum, PVC pipe, T connection, door slot, door hinges, reservoir ring, water faucet, pipe glue, scrap drum, pipe seal tape.

\section{Tool Design and Testing}

The design of the composter tool is done by sketching the image using the AutoCAD application. The design is then carried out by assembling the tool. The assembled composer was then tested. The trial was carried out with parameter monitoring. The parameters observed included the size of the chopped particles, the capacity of organic waste and the length of time for chopping.

\section{Analysis}

The observation consists of three stages. The first observation was carried out by measuring the results of the organic waste chopper using a ruler, the second stage the results of the chopper being weighed using a digital weighing device to determine the weight of the chopped results, the third measuring the duration for chopping the organic waste using a stopwatch. The trial was conducted to determine the ability of the composter designed to carry out the composting process. After the trial is complete, the next tool evaluation analysis is carried out.

\section{RESULTS AND DISCUSSION}

The flow analysis of the composting process in this study includes the process of processing waste from taking household waste to the organic compost production process which is described in the form of a flow chart as follows: 


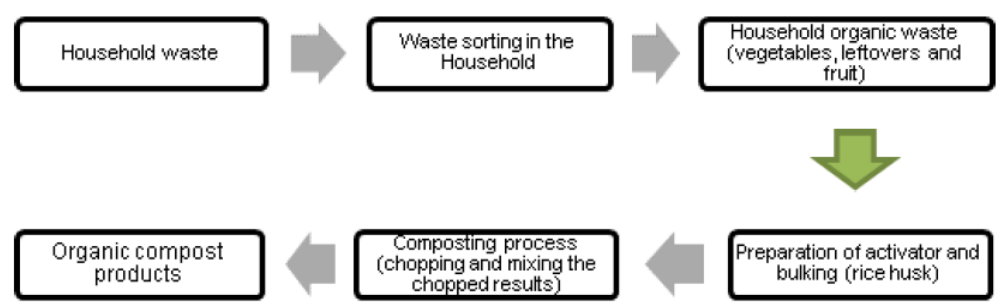

Figure 1. Flowchart of household organic compost production process.

In the process of making compost, it requires a process of shredding/chopping organic waste, such as vegetables and fruits into small pieces. The chopper is made portable so it is easy to operate and easy to move outside or inside the bin. The materials that can be chopped in this process are organic materials. The chopping mechanism uses a single-axis rotary blade, which consists of 12 blades. The blades are bolted together, it can be removed for sharpening if they are dull, and then reattached with ease. The results of the chopping machine in the form of small pieces will come out through the outlet.

The design of the composting machine adjusts the height of the general public by paying attention to the safety and comfort of the user ${ }^{[8]}$. The chopping cylinder with compost storage drawer uses materials in the form of stainless still so that rust or corrosion does not occur as a result of organic waste that contains a lot of water [9]. The main source of waste in Indonesia is household, most of which $(50-60 \%)$ is waste that easily decomposes. Decomposing garbage comes from leftover food, fruits, vegetables and so on. Some household waste in Indonesia is underutilized and tends to use the collection and disposal method in Temporary Disposal Sites (TPS) and Final Disposal Sites (TPA). Only a small part of household waste is processed into fertilizer. Organic waste counting is an important process in making compost. The process of chopping up waste/organic materials such as household waste, leaves and others can be done manually. Household organic waste is vegetable residue, fruit residue and others that are quite large in size. The waste needs to be processed further so that it has a smaller size [10].

The composter design is described in the form of tool design as follows:
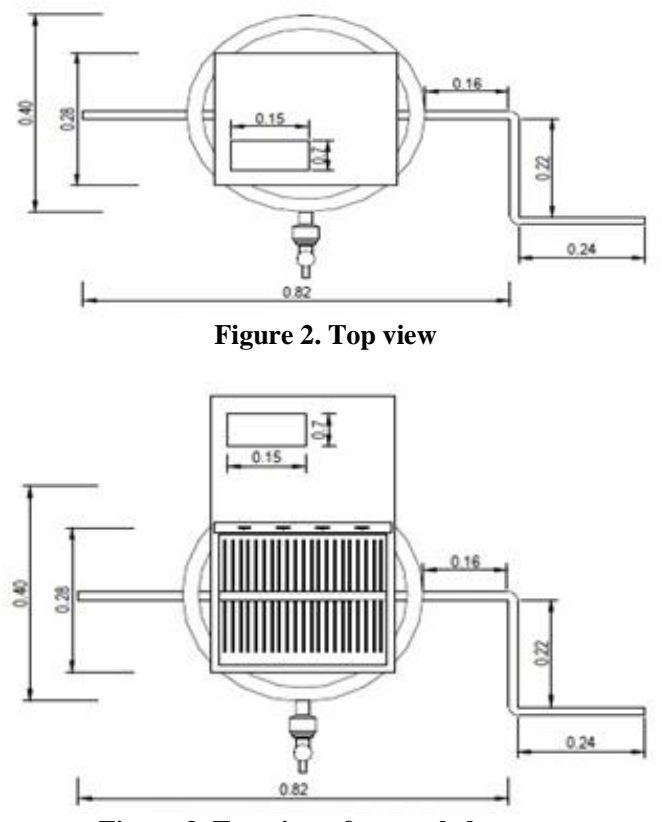

Figure 3. Top view of manual chopper

The image below is a tool that has been successfully made according to the design that has been done previously. There is a picture of a combined chopping machine with a drum. The size of this tool consists of Height $=100 \mathrm{~cm}$, Diameter $=45$ $\mathrm{cm}$, and Volume $150 \mathrm{~L}$.

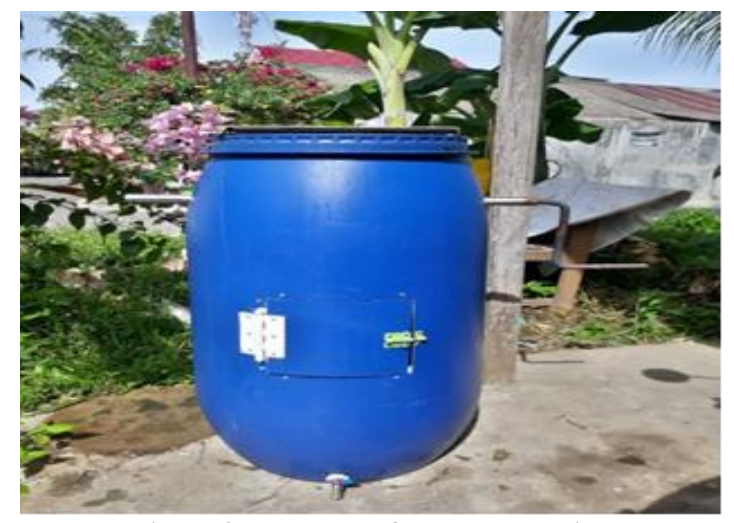

Figure 4. The result of composter design 


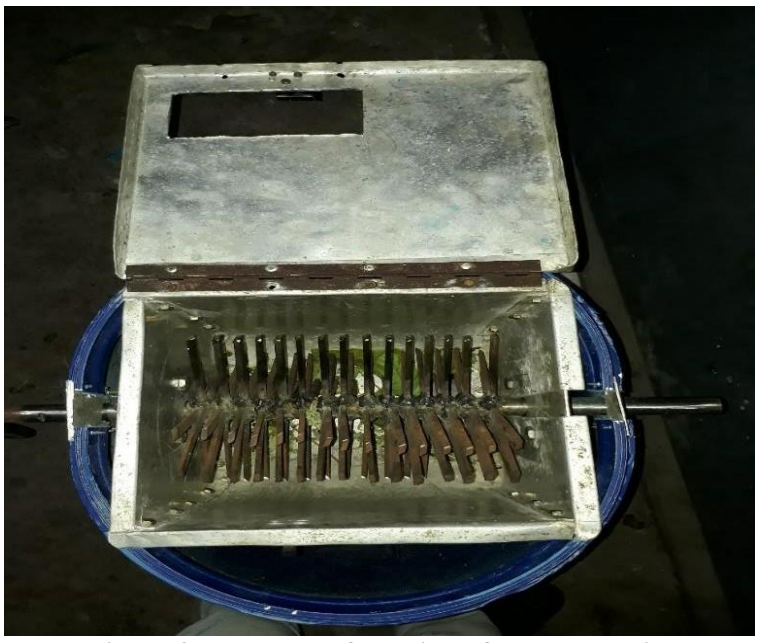

Figure 4. The result of top view of composter bin

Household-scale organic waste counting equipment is made using materials that are not easily damaged due to the presence of decomposing bacteria which are usually found in organic waste. The volume of organic waste that has been chopped can be reduced up to $50 \%$ and the material can be used as a basic material for making compost. The raw compost material should have dry conditions in order to avoid chopping waste with a mud texture which can result in jamming the use of organic chopping equipment ${ }^{[11]}$.

The implementation of the compost bin design is that physically the size of the composter is $100 \mathrm{~cm}$ high and $45 \mathrm{~cm}$ in diameter. with this size the compost material that can be processed is equivalent to $22,735 \mathrm{~kg}$ in one process. The chopper system consists of a manually actuated lever connected to the chopping blades so that the chopper blade rotates. Tongposcah functional test was carried out and the results showed that the composter designed in this study was able to work stably for 75 minutes until the bin is full, due to manual motion that was rotated by human power.

The performance of the compost bin in the process of composting waste into organic compost, includes a mechanical composter work test, and the compost production process. The compost bin is able to accommodate a maximum of $15-60 \mathrm{~kg}$ of household waste, the stirrer system can rotate stably, the mixing of organic waste compost material has been stable (homogeneous), the air ventilation system as a temperature regulation can work well, the entrance and exit of compost material at the composter works well, the composter legs are sturdy and strong against rotational vibrations, the composter chopper drive lever through the rotating wheel can rotate well, the composter can hold liquid compost from leakage.

Volume of leachate storage $=20 \% \mathrm{x}$ Total volume of composter

$=20 \% \times 150 \mathrm{~L}$

$=30 \mathrm{~L}$

The height of the chopper $=30 \% \mathrm{x}$ Total height of the composter

$=30 \% \times 100 \mathrm{~cm}$

$=30 \mathrm{~cm}$

The volume of the compost bin $=$ (Total volume of the composter - Volume of the chopper)

- Volume of leachate reservoir

$=(150 \mathrm{~L}-45 \mathrm{~L})-30 \mathrm{~L}$

$=105 \mathrm{~L}-30 \mathrm{~L}$

$=75 \mathrm{~L}$

Height of leachate reservoir $=20 \% \times$ Total height of composter

$=20 \% \times 100 \mathrm{~cm}$

$=20 \mathrm{~cm}$

Height of compost storage $=$ Total height of composter - Height of chopper equipment Height of leachate storage

$=100 \mathrm{~cm}-30 \mathrm{~cm}-20 \mathrm{~cm}=50 \mathrm{~cm}$

\section{CONCLUSIONS}

Overview mechanically Tongposcah is able to accommodate a maximum of 15$60 \mathrm{~kg}$ of household waste, the stirrer system can rotate stably, the mixing of organic waste compost material has been stable (homogeneous), the air ventilation system as a temperature regulation can work well, the entrance and exit of compost material at the composter works well, the composter legs are sturdy and strong against rotational vibrations, the composter chopper drive lever through the rotating wheel can rotate well, the composter can hold liquid compost from leakage.

It is necessary to make improvements of the composter tool, 
especially in the shape of the chopper blade. Further research is needed on the operation to be applied in the composting process.

\section{ACKNOWLEDGMENTS}

This research supported by LPPM PNBP of Lambung Mangkurat University Indonesia contract number 009.40/UN8.2/PL/2021 1 April 2021.

\section{Conflict of Interest: None}

\section{Source of Funding: None}

\section{REFERENCES}

1. Republik Indonesia. 2008. Undang-Undang Republik Indonesia Nomor 18 Tahun 2008 tentang Pengelolaan Sampah. Jakarta.

2. Rizkiannur, M. (2019). "Studi timbulan, Komposisi dan Karakteristik Sampah Domestik Kota Banjar Baru", Skripsi/Tugas Akhir Program Studi Teknik Lingkungan. Universitas Lambung Mangkurat. Banjarbaru.

3. Sunarti, E. A \& Djamalu, Yunita. (2018). "Desain Mesin Pencacah Sampah Organik Rumah Tangga untuk Pembuatan Pupuk Kompos. JTech 8(1): 47-51.

4. Badan Standarisasi Nasional (2008). "Pengelolaan Sampah dipermukiman". Badan Standarisasi Nasional, pp. 1-23.

5. Hendaryanto, I. A., (2018). "Pembuatan Mesin Pencacah Sampah Organik Untuk Swadaya Pupuk di Desa Tancep Kecamatan Ngawen Kabupaten Gunung Kidul”.
Departemen Teknik Mesin Sekolah Vokasi Universitas Gadjah Mada.

6. Nugraha, N., Anggraeni, N. D., Ridwan, M., Fauzi, O., \& Yusuf, D. (2017). "Rancangan Bangunan Komposter Rumah Tangga Komunal Sebagai Solusi Pengelolaan Sampah Mandiri Kelurahan Pasir Jati Bandung. CR Journal, 1- 114.

7. Pengelolaan Sampah Mandiri Kelurahan Pasir Jati Bandung. CR Journal, 1- 114.

8. Rizkiannur, M. (2019). "Studi timbulan, Komposisi dan Karakteristik Sampah Domestik Kota Banjar Baru", Skripsi/Tugas Akhir Program Studi Teknik Lingkungan. Universitas Lambung Mangkurat. Banjarbaru.

9. Sunarti, E. A \& Djamalu, Yunita. (2018). "Desain Mesin Pencacah Sampah Organik Rumah Tangga untuk Pembuatan Pupuk Kompos. JTech 8(1): 47-51.

10. Surya, A., Azharul, F., \& Wilarso. (2019). "Rancangan Bangun Alat Penghancur Sampah Orgnaik Skala Rumah Tangga". Program Studi Teknik Mesin. Sekolah Tinggi Teknologi Muhammadiyah Cileungsi. JMEMME 3(2): 92-99.

11. Wirawan, I.K.G., Sugita, I.K.G., Suarda, M., \& Astawa, K. (2020). "Mesin Pencacah Sampah Organik Skala Rumah Tangga". Program Studi Teknik Mesin. Universitas Udayana. Vol.19 (1): 100-105.

How to cite this article: Rizqi Puteri Mahyudin, Gamaliel Purba, Yuni Safaria Dwi Lestari et.al. Design of household organic waste composter bins "Tongposcah". International Journal of Research and Review. 2022; 9(1): 630-634. DOI: https://doi.org/10.52403/ijrr.20220173 